\title{
Does Income Smoothing Improve Earnings Informativeness?
}

\author{
X. Jenny Tucker \\ Fisher School of Accounting \\ Warrington College of Business \\ University of Florida \\ 310 Gerson Hall \\ Gainesville, FL 32611 \\ (352)273-0214 \\ jenny.tucker@cba.ufl.edu \\ Paul Zarowin \\ Stern School of Business \\ New York University \\ 44 W. Fourth Street, KMC 10-90 \\ New York, NY 10012 \\ (212)998-0015 \\ pzarowin@stern.nyu.edu
}

June 2005

We thank the helpful comments from Joel Demski and participants of the workshops at New York University and London Business School. 


\title{
Does Income Smoothing Improve Earnings Informativeness?
}

\begin{abstract}
This paper uses a new approach to examine whether income smoothing garbles earnings information or improves the informativeness of past and current earnings about future earnings and cash flows. We measure income smoothing by the negative correlation of a firm's change in discretionary accruals with its change in pre-managed earnings. Using the approach of Collins, Kothari, Shanken and Sloan (1994), we find that change in the current stock price of higher-smoothing firms contains more information about their future earnings than does change in the stock price of lower-smoothing firms. This result is robust to decomposing earnings into cash flows and accruals and to controlling for firm size, growth, future earnings variability, private information search activities, and cross-sectional correlations.
\end{abstract}




\section{Does Income Smoothing Improve Earnings Informativeness?}

\section{INTRODUCTION}

In this paper we use a new approach to investigate whether income smoothing garbles accounting earnings information or improves the informativeness of firms' reported current and past earnings about their future earnings and cash flows. Income smoothing represents managers' attempts to use their reporting discretion to "intentionally dampen the fluctuations of their firms' earnings realizations" (Beidleman 1973, 653). Although income smoothing has been widely documented for decades ${ }^{1}$, its effect on earnings informativeness is largely unknown. On one hand, income smoothing improves earnings informativeness if managers use their discretion to communicate their assessment of future earnings. On the other hand, income smoothing makes earnings noisier if managers intentionally distort the earnings numbers. Which effect dominates in a cross-sectional setting is an open, empirical question. Our study contributes to the literature by shedding new light on this information-vs-garbling debate.

Although we examine managers' discretionary reporting behavior, our study differs from most earnings management studies, which focus on the costs of earnings management (Teoh, Welch and Wong 1998; Marquardt and Wiedman 2005; Bartov and Mohanram 2004, etc.). We focus on the benefits of discretionary behavior. Our primary contribution is to use the approach of Collins, Kothari, Shanken and Sloan (CKSS, 1994) and provide evidence that income smoothing improves the informativeness of past and current earnings about future earnings and cash flows. We do so by investigating the association between current-year stock returns and future earnings for firms with

\footnotetext{
${ }^{1}$ See Beidleman (1973), Ronen and Sadan (1981), Schipper (1989), Subramanyam (1996) and Healy and Wahlen (2000).
} 
different degrees of smoothing. We refer to this association as the future earnings response coefficient (FERC).

Assuming the informational efficiency of stock price, the CKSS approach examines how much information about future earnings is reflected in the change in current stock price. This approach is superior to estimating the direct relation between a firm's future earnings and its current and past earnings for two reasons. First, although realized earnings are often used to directly predict future earnings, the earnings information can be indirectly used by investors in earnings predictions when investors combine it with information from other sources (Christensen and Demski 2003, Chapter 10). By using the stock price, which aggregates all publicly available information, the CKSS approach considers both the direct and the indirect roles of realized earnings. Second, the change in (expected) future earnings may be due to a shock that has no effect on current earnings. ${ }^{2}$ Such information will not be captured by current earnings, but will be impounded in current stock price.

Our paper is closely related to two recent studies. Subramanyam (1996) finds that returns are positively associated with contemporaneous discretionary accruals, while Hunt, Moyer and Shevlin (2000) report that income smoothing enhances the contemporaneous price-earnings relation. Both papers focus on the relation between prices (or returns) and contemporaneous accounting information. In contrast, we focus on the relation between returns and future accounting information. Enhancing the relation between price (or return) and contemporaneous earnings could be due to lower risk and/or greater persistence rather than to increased informativeness about the future. If

\footnotetext{
${ }^{2}$ An example would be an announcement of a new product that will not be commercially available until a future period.
} 
income smoothing makes earnings more informative, returns should reflect more information about future earnings, and the FERC should be higher for firms with greater smoothing. If income smoothing merely garbles information, returns should reflect less future earnings information, and the FERC should be lower for firms with greater smoothing. Thus, our focus allows better assessment of the informativeness of a firm's current and past earnings about future earnings.

We measure income smoothing as the negative correlation of a firm's change in discretionary accruals with its change in pre-managed income. A more negative correlation indicates more income smoothing. Using data from post-1988 we find that firms with greater smoothing have higher FERC. This result is robust to decomposing earnings into cash flows and accruals; to controlling for firm size, growth, future earnings variability, and private information search activities (proxied by analyst following and institutional holdings); and to separating loss firms from profit firms. In addition, to address potential cross-sectional correlations in the pooled regressions, we extend the data to pre-1988 so that the number of cross-sections is large enough for the FamaMacBeth (1973) analysis. We find a similar, though weaker, result.

Despite the above evidence, our findings should be interpreted with caution for two reasons. First, market efficiency is assumed in all the tests. If the equity markets are inefficient, the interpretation of our findings is unclear. Second, because managers' discretionary behavior is unobservable, our income-smoothing measure suffers from potential measurement error problems, something that affects many other earnings management studies. We estimate discretionary accruals using the method of Kothari, Leone and Wasley (2004), which controls for measurement error in well- or poorly- 
performing firms. Nevertheless, despite our attempts to ensure that the measurement error in the discretionary accruals proxy is not driving the results, we cannot rule out measurement error as an alternative explanation for our results.

The rest of this paper is organized as follows. Section II reviews previous research on the motivations and effects of income smoothing. Section III explains our research design. Section IV discusses the data and presents the main empirical results. Section V reports the robustness tests and Section VI concludes.

\section{INCOME SMOOTHING: MOTIVATIONS AND EFFECTS}

Income smoothing, which Arthur Levitt labeled "cookie jar" accounting in his 1998 speech, is not a new issue. Gordon $(1964,262)$ predicts that as long as managers have discretion over accounting choices, they smooth reported income and the rate of growth in income. His prediction was tested in several studies. By the late 1970s, evidence for income smoothing was plentiful (Beidleman 1973; Ronen and Sadan 1981).

Recent research has enriched our understanding of managers' use of their reporting discretion, categorizing it as either (i) garbling or (ii) efficient communication of private information. Managers may smooth reported income to meet the bonus target (Healy 1985) or to protect their job (Fudenberg and Tirole 1995; Arya, Glover and Sunder 1998). The contracting theory argues that income garbling is an equilibrium solution because the principal would otherwise pay a high premium to compensate the agent, who has the information advantage, for taking additional risk (Lambert 1984; Demski and Frimor 1999). In these circumstances, even if the contract is efficient, the communication has been garbled and thus the reported earnings are less informative about a firm's future earnings and cash flows. 
In contrast, other studies view income smoothing as a vehicle for managers to reveal their private information about future earnings (Kirschenheiter and Melumad 2002; Ronen and Sadan 1981; Sankar and Subramanyam 2001; Demski 1998). Such communication could be either active or passive. For example, Kirschenheiter and Melumad show that reported earnings have dual roles. The level of reported earnings allows investors to infer the level of permanent future cash flows. The fluctuations of reported earnings reduce investors' confidence in the inferred permanent component. The dual roles cause managers to smooth earnings. ${ }^{3}$ Using Spence's (1973) signaling framework, Ronen and Sadan argue that only firms with good future prospects smooth earnings because borrowing from the future could be disastrous to a poorly performing firm when the problem explodes in the near term.

Private information about future earnings can also be communicated passively. Sankar and Subramanyam (2001) demonstrate that managers smooth income to smooth consumption and that in so doing they reveal private information about future earnings. Demski (1998) shows that, even in the absence of an incentive, future earnings are partially communicated in efficient contracting as long as managers use future earnings information to decide whether they smooth current earnings. Whether information is communicated actively or passively, income smoothing could make firms' current and past earnings more informative about future earnings and cash flows.

Note that the garbling versus information views lead to diametrically opposite predictions. If income smoothing is merely garbling, earnings of firms that experience more smoothing should be less informative about future earnings. If income smoothing is

\footnotetext{
${ }^{3}$ Trueman and Titman (1988) find that firms smooth earnings to reduce the cost of borrowing and to favorably affect the terms of trade with suppliers and customers.
} 
used to convey private information, the relation between current (including past) earnings and future earnings should be strengthened and, for the reason to be explained in the next section, the FERC is expected to be higher as well. Which effect dominates in a crosssectional setting is an unanswered, empirical question that we address.

Two previous empirical studies are closely related to ours. Using the cross-sectional Jones model, Subramanyam (1996) finds that returns are positively associated with contemporaneous discretionary accruals, and that discretionary accruals are positively associated with future earnings and operating cash flows, implying that discretionary accruals convey information about firms' future prospects. He also finds that the correlation between discretionary accruals and pre-discretionary income is negative, concluding that firms engage in income smoothing. Hunt, Moyer and Shevlin (2000) find that income smoothing enhances the contemporaneous price-earnings relation, suggesting that income smoothing improves earnings informativeness. Both papers focus on the relation between prices or returns and contemporaneous accounting information. As we explained in Section I, we adopt a different approach that focuses on the relation between returns and future accounting information.

\section{RESEARCH DESIGN}

In this section we explain how we measure income smoothing, argue why the FERC captures earnings informativeness about future earnings, and present our primary and supplementary econometric models. 


\section{Income-Smoothing Measure}

Income smoothing is defined as “an attempt on the part of the firm's management to reduce abnormal variations in earnings to the extent allowed under sound accounting and management principles" (Beidleman 1973, 653). Following Myers and Skinner (2002) and Leuz, Nanda and Wysocki (2003), we measure income smoothing by the negative correlation between the change in discretionary-accruals proxy (" $\Delta \mathrm{DAP}$ ") and change in pre-discretionary income (“ $\triangle \mathrm{PDI}$ ). This measure assumes that there is an underlying pre-managed income series and that managers use discretionary accruals to make the reported series smooth. More income smoothing is evident in a more negative correlation between $\triangle \mathrm{DAP}$ and $\triangle \mathrm{PDI}$.

To estimate discretionary accruals, we use the cross-sectional version of the Jones model, modified by Kothari, Leone and Wasley (2004).

$$
\text { Accruals }_{t}=a\left(1 / \text { Assets }_{t-1}\right)+b_{\Delta} \text { Sales }_{t}+c P \text { PPE }_{t}+\text { d ROA }_{t}+\mu_{t}
$$

In Regression (1), the total accruals (Accruals); change in sales ( $\Delta$ Sales); and gross property, plant, and equipment (PPE) are each deflated by the beginning-of-year total assets (Assets). ${ }^{4}$ Return on assets (ROA) is added as an additional control variable, because previous research finds that the Jones model is misspecified for well-performing or poorly-performing firms (Dechow, Hutton and Sloan 1996; Kothari, Leone and Wasley 2004).

To employ a large number of observations, we run the regression on all firms in the same industry (2-digit SIC) each year. The non-discretionary accruals (NDAP) are the fitted values of Regression (1) and the discretionary accruals (DAP) are the deviations of

\footnotetext{
4 "Accruals" are net income minus CFO, where CFO is obtained from the cash flow statements. "Net income", "CFO", "Sales", "PPE," and "Assets" are the variables Data18, Data308, Data12, Data7, and Data6 in the Compustat's combined industry annual data file, respectively.
} 
actual accruals from NDAP. The pre-discretionary income (PDI) is calculated using the "backing out" approach: net income minus discretionary accruals (PDI = NI - DAP).

The income-smoothing measure is the correlation between the change in discretionary accruals and change in pre-discretionary income: Corr ( $\triangle \mathrm{DAP}, \Delta \mathrm{PDI})$, using the current year's and past four years' observations. The use of five observations is a tradeoff between a sufficiently long time-series for the income-smoothing measure and a large sample to test the model. We use annual data because there is much evidence that firms smooth fiscal-year earnings and that fourth-quarter reporting is distinctively different from that of other quarters (Jacob and Jorgensen 2003; Das and Shroff 2002). To control for industry and time effects, we use a firm's reversed fractional ranking of income smoothing (between 0 and 1) within its industry-year (2-digit SIC) and refer to it as "IS." As a result, firms with a more negative correlation receive a higher incomesmoothing ranking. ${ }^{5}$

\section{FERC and Earnings Informativeness}

Figure 1 illustrates the relation between FERC and earnings informativeness. ${ }^{6}$ Because business operating cycles are continuous, when a firm gradually realizes its current earnings it has certain private knowledge about the future earnings. ${ }^{7}$ The more information a firm has about the future, the more successfully it can smooth its income series. Consequently, information about future earnings is revealed by a firm's reporting behavior well before the earnings are recognized. The information is reflected in the

\footnotetext{
${ }^{5} \mathrm{~A}$ fractional ranking is the raw rank divided by the number of observations. For example, the fractional rankings of 1 and 10 among the numbers 1 to 10 are 0.1 and 1 , respectively.

${ }^{6}$ We thank an anonymous referee for suggesting Figure 1.

${ }^{7}$ Although earnings are reported quarterly, the information about earnings arrives at the market continuously (Ball and Brown 1968, Figure 1).
} 
change in current stock price, which aggregates the information with other sources of public signals through the force of market arbitrage and in the process of price discovery. Thus, the change in current stock price captures the change in investors' expectation for future earnings. The strength of this relation is measured by the FERC in the CKSS framework.

\section{Primary and Supplementary Models}

The CKSS framework has its theoretical underpinning in the discounted cash flows valuation model. By assuming that investors' revisions in dividend expectations are fully summarized by their revisions in earnings expectations, CKSS model the return-earnings relation as Regression (2).

$$
R_{t}=\alpha_{0}+\beta_{1} U X_{t}+\sum_{k=1}^{3} \gamma_{k} \Delta E_{t}\left(X_{t+k}\right)+\varepsilon_{t}
$$

where, $R_{t}$ is the ex-dividend annual stock return for Year $t, U X_{t}$ is the difference between the realized earnings for Year $t$ and what was expected at the beginning of the year, $X_{t+k}$ is the reported earnings for Year $\mathrm{t}+\mathrm{k}$, and $\Delta E_{t}\left(X_{t+k}\right)$ is the change in expectations between the end and beginning of Year $\mathrm{t}$ for earnings in Year $\mathrm{t}+\mathrm{k} .{ }^{8}$ Here, $\beta_{1}$ is the ERC, $\gamma_{k}$ is the FERC for Year $\mathrm{t}+\mathrm{k}$, and both are predicted to be positive.

Because investors' earnings expectations are unobservable, implementing the model requires the use of proxies. CKSS use the reported earnings for Year t-1 as the proxy for the expectation component of $U X_{t}$. Because the expectation is subtracted from realized earnings, the coefficient on past earnings should be negative. For $\Delta E_{t}\left(X_{t+k}\right)$, CKSS use

\footnotetext{
${ }^{8}$ By "Year", we mean "Fiscal Year" throughout the paper.
} 
the realized earnings for Year $\mathrm{t}+\mathrm{k}$ as a proxy for the expectation formed at the end of Year $\mathrm{t}$, and use past earnings to form an expectation at the beginning of Year $\mathrm{t}$. To reduce the measurement error problem in using realized earnings (Year $\mathrm{t}+\mathrm{k}$ ) for expected earnings (expectation formed at the end of Year t), CKSS include future returns. The logic is that if realized earnings are higher (lower) than expectation, stock price should increase (decrease) accordingly from Year $\mathrm{t}+1$ to $\mathrm{t}+\mathrm{k}$. This positive correlation leads to a negative loading on the future returns variable in the regression.

CKSS use earnings changes as the independent variables, implicitly assuming that annual earnings follow a random walk. Lundholm and Myers (2002) use the levels of past, current, and future earnings to allow for a more general form of earnings expectations model. To increase the power of test, Lundholm and Myers combine the three future years' earnings into variable $\mathrm{X}_{\mathrm{t} 3}$ and the three future years' returns into $\mathrm{R}_{\mathrm{t} 3}$. As a result, we implement the CKSS approach by Regression (3).

$$
\mathrm{R}_{\mathrm{t}}=\mathrm{b}_{0}+\mathrm{b}_{1} \mathrm{X}_{\mathrm{t}-1}+\mathrm{b}_{2} \mathrm{X}_{\mathrm{t}}+\mathrm{b}_{3} \mathrm{X}_{\mathrm{t} 3}+\mathrm{b}_{4} \mathrm{R}_{\mathrm{t} 3}+\varepsilon_{\mathrm{t}}
$$

In (3), $\mathrm{X}_{\mathrm{t}-1}$ and $\mathrm{X}_{\mathrm{t}}$ are the earnings per share (EPS) for Year $\mathrm{t}-1$ and $\mathrm{t}$, respectively, and $X_{t 3}$ is the sum of EPS for Year $t+1$ to $t+3$. All the EPS variables are the basic EPS excluding extraordinary items (Compustat Data58), adjusted for stock splits and stock dividends, and, according to Christie (1987), deflated by the stock price at the beginning of Year $t . R_{t 3}$ is the aggregate stock return in Year $t+1$ to $t+3$ with annual compounding. The coefficient on past earnings $\left(b_{1}\right)$ is predicted to be negative, the ERC $\left(b_{2}\right)$ is predicted to be positive, the FERC $\left(b_{3}\right)$ is predicted to be positive, and the coefficient on future returns $\left(b_{4}\right)$ is predicted to be negative. 
To address our research question, we expand the above regression by adding the income-smoothing measure "IS" and its interactions with the existing independent variables. Regression (4) is our primary empirical model:

$$
\begin{aligned}
\mathrm{R}_{\mathrm{t}}=\mathrm{b}_{0}+ & \mathrm{b}_{1} \mathrm{X}_{\mathrm{t}-1}+\mathrm{b}_{2} \mathrm{X}_{\mathrm{t}}+\mathrm{b}_{3} \mathrm{X}_{\mathrm{t} 3}+\mathrm{b}_{4} \mathrm{R}_{\mathrm{t} 3} \\
& +\mathrm{b}_{5} \mathrm{IS}_{\mathrm{t}}+\mathrm{b}_{6} \mathrm{IS}_{\mathrm{t}} * \mathrm{X}_{\mathrm{t}-1}+\mathrm{b}_{7} \mathrm{IS}_{\mathrm{t}} * \mathrm{X}_{\mathrm{t}}+\mathrm{b}_{8} \mathrm{IS}_{\mathrm{t}} * \mathrm{X}_{\mathrm{t} 3}+\mathrm{b}_{9} \mathrm{IS}_{\mathrm{t}} * \mathrm{R}_{\mathrm{t} 3}+\varepsilon_{\mathrm{t}}
\end{aligned}
$$

We estimate (4) on pooled cross-sectional, time-series data. If the dominating effect of income smoothing is to convey information about future earnings, the coefficient on "IS $\mathrm{S}_{\mathrm{t}} * \mathrm{X}_{\mathrm{t}}$ " should be positive. If the garbling effect of income smoothing dominates, earnings would be less informative and thus the coefficient is expected to be negative.

As we explained in Section I, using stock price has an advantage over estimating the relation between current earnings and future earnings. Despite the difference, the two tests are related. If income smoothing improves earnings informativeness, it must strengthen the relation between future earnings and current earnings - i.e., it must increase earnings persistence. To confirm this, we estimate the relation between current and future earnings in Regression (5).

$$
\text { EPS }_{\mathrm{t} 3}=\mathrm{a}_{0}+\mathrm{a}_{1} \text { EPS }_{\mathrm{t}}+\mathrm{a}_{2} \text { IS }_{\mathrm{t}}+\mathrm{a}_{3} \text { IS }_{\mathrm{t}} * \text { EPS }_{\mathrm{t}}+\varepsilon_{\mathrm{t}}
$$

Here, $\mathrm{EPS}_{\mathrm{t}}$ is the EPS for fiscal year $t$ and $\mathrm{EPS}_{\mathrm{t} 3}$ is the sum of EPS in fiscal year $t+1$ to $t+3$, both undeflated. Our interest is the coefficient on IS $t *$ EPS $t$, which should be positive if income smoothing strengthens the relation between current and future earnings.

\section{DATA AND MAIN EMPIRICAL RESULTS}

We use the 2004 version of Compustat's combined industrial annual data file and choose 1993-2000 as the sample period for the primary test. The period begins with 1993 
because 1988 is the first year in which firms are required to report cash flow statements, and we use five observations of $\triangle \mathrm{DAP}$ and $\triangle \mathrm{PDI}$ to calculate the income-smoothing measure. Firms in the financial and regulated industries are excluded due to their unique nature of accounting (SIC 4000-4999 and 6000-6999).

\section{Estimation of Discretionary Accruals}

For this estimation, we use the data from 1988-2000 and run Regression (1) on each of the 650 industry-year cross-sections, after excluding 110 cross-sections that have fewer than 10 observations and winsorizing the regression variables at the three standardization deviations each year. Table 1 presents the mean, standard deviation, median, minimum, and maximum of the coefficient estimates and $\mathrm{R}^{2}$. The average $\mathrm{R}^{2}$ is 0.642 , indicating that about $2 / 3$ of the cross-sectional variation in firms' total accruals is

explained by the identified independent variables. The coefficients on "1/Assetst-1" and "PPE" are comparable to those reported in Subramanyam (1996), and the coefficient on " $\Delta$ Sales" $"$ is lower than that in Subramanyam due to our additional control for earnings performance. A firm's asset-deflated nondiscretionary and discretionary accruals are the fitted values and residuals, respectively.

\section{Income-Smoothing Measure and Data Cleaning}

PDI is calculated as net income minus DAP, both deflated by the beginning-of-year total assets. A firm-year observation is deleted if its $\triangle \mathrm{DAP}$ or $\triangle \mathrm{PDI}$ is missing in the current year and the past five years. The income-smoothing measure is calculated for the remaining firm-year observations. 
For the primary test, we delete the firm-year observations that have missing data for past, current, and future three years' earnings, operating cash flows, and accruals as well as those for current and future three years' returns. To minimize the effect of outliers, we delete the observations that are in the top or bottom $1 \%$ of the distributions of the above variables. Even with this effort, extreme outliers are still observed. We further delete the observations whose earnings, operating cash flows, or total accruals in the past, current, or any of the future three years are greater than 10 times or less than -10 times the market equity value, or whose future three years' compound returns are greater than 10 or less than -10 . These procedures result in 17, 019 observations for the primary test.

\section{Primary Model Test Results}

Panel A of Table 2 provides the descriptive statistics of the 17,019 sample observations. The first five rows list the variables in the primary test. "Accruals" and "CFO" will be used in the extended model for a robustness test. The last two rows provide information about the raw income-smoothing measure and DAP.

Panel B of Table 2 presents the pairwise correlations between the variables used in Regression (4). The raw income-smoothing measure is negatively associated with past, current, and future earnings. This indicates that firms with better performance smooth income to a larger degree, consistent with the prediction of the signaling argument as discussed in Section II.

Table 3 reports the main test results. First, in Panel A we present the results of Regression (5), the traditional earnings persistence model. ${ }^{9}$ As predicted, the coefficient

\footnotetext{
${ }^{9}$ The results are similar if the EPS variables are deflated by the stock price at the beginning of Year $t$.
} 
on the interaction between IS and EPS is significantly positive $\left(a_{3}=0.703\right.$, t-statistic $=$ 11.24), confirming that income smoothing strengthens earnings persistence.

Second, to compare with previous research using CKSS, in Panel B we present the results of the benchmark CKSS model (Regression (3)). As predicted, both the ERC and FERC are significantly positive. The positive FERC indicates that a significant amount of information about future earnings has been impounded in current stock price. The coefficient on past earnings and future returns are both negative, as predicted.

Panel C reports the results of our primary model. After we include the incomesmoothing variable IS, the interaction term " $\mathrm{IS}_{\mathrm{t}}{ }^{*} \mathrm{X}_{\mathrm{t}}$ " has a significantly positive loading $\left(b_{8}=0.308\right.$, t-statistic $\left.=4.99\right)$, indicating that income smoothing enhances the FERC. The evidence supports the view that income smoothing improves the informativeness of past and current earnings about future earnings. Income smoothing also improves the ERC, evidenced by the significantly positive coefficient on " $\mathrm{IS}_{\mathrm{t}} * \mathrm{X}_{\mathrm{t}}$ " $\left(\mathrm{b}_{7}=0.681\right.$, t-statistic $=$ 4.08), consistent with Hunt et al. (2000).

The coefficients on $\mathrm{IS}_{\mathrm{t}}$ and $\mathrm{IS}_{\mathrm{t}}{ }^{*} \mathrm{X}_{\mathrm{t}-1}\left(\mathrm{~b}_{5}\right.$ and $\left.\mathrm{b}_{6}\right)$ are both significant, confirming their importance as control variables, even though we are primarily interested in the effect of smoothing on FERC and ERC $\left(b_{8}\right.$ and $\left.b_{7}\right)$. Although the interaction " $\mathrm{IS}_{\mathrm{t}}{ }^{*} \mathrm{X}_{\mathrm{t}}$ " is significantly positive, the coefficient on $\mathrm{X}_{\mathrm{t} 3}$ loses its significance after the inclusion of income smoothing. This suggests that stock price impounds information about future earnings only in the presence of income smoothing.

\section{EXTENSION AND ROBUSTNESS TESTS}

We have several concerns about the primary model. In this section we report how we extend the model to address these concerns. 


\section{Decomposing Earnings into Cash Flows and Accruals}

Although earnings are positively correlated with operating cash flows, predicting cash flows is the main task of equity valuation. Thus, we extend the model to examine whether income smoothing allows more information about future cash flows to be impounded in current stock price. ${ }^{10}$ In Regression (6), we decompose earnings into CFO and accruals ("ACC"). Our key interest is the interaction between income smoothing and future cash flows $\left(\mathrm{IS}_{\mathrm{t}} * \mathrm{CFO}_{\mathrm{t} 3}\right)$. If income smoothing enhances earnings informativeness about future cash flows, the coefficient $b_{11}$ should be positive; if income smoothing garbles information, $b_{11}$ should be negative. Because we are unaware of any theory of or empirical evidence on how income smoothing affects the predictability of future accruals, we have no prediction for the coefficient on IS $t_{t} \mathrm{ACC}_{\mathrm{t} 3}$.

$$
\begin{aligned}
\mathrm{R}_{\mathrm{t}}= & \mathrm{b}_{0}+\mathrm{b}_{1} \mathrm{CFO}_{\mathrm{t}-1}+\mathrm{b}_{2} \mathrm{CFO}_{\mathrm{t}}+\mathrm{b}_{3} \mathrm{CFO}_{\mathrm{t} 3}+\mathrm{b}_{4} \mathrm{ACC}_{\mathrm{t}-1}+\mathrm{b}_{5} \mathrm{ACC}_{\mathrm{t}}+\mathrm{b}_{6} \mathrm{ACC}_{\mathrm{t} 3}+\mathrm{b}_{7} \mathrm{R}_{\mathrm{t} 3} \\
& +\mathrm{b}_{8} \mathrm{IS}_{\mathrm{t}}+\mathrm{b}_{9} \mathrm{IS}_{\mathrm{t}} * \mathrm{CFO}_{\mathrm{t}-1}+\mathrm{b}_{10} \mathrm{IS}_{\mathrm{t}} * \mathrm{CFO}_{\mathrm{t}}+\mathrm{b}_{11} \mathrm{IS}_{\mathrm{t}} * \mathrm{CFO}_{\mathrm{t} 3} \\
& +\mathrm{b}_{12} \mathrm{IS}_{\mathrm{t}} * \mathrm{ACC}_{\mathrm{t}-1}+\mathrm{b}_{13} \mathrm{IS}_{\mathrm{t}} * \mathrm{ACC}_{\mathrm{t}}+\mathrm{b}_{14} \mathrm{IS}_{\mathrm{t}} * \mathrm{ACC}_{\mathrm{t} 3}+\mathrm{b}_{15} \mathrm{IS}_{\mathrm{t}} * \mathrm{R}_{\mathrm{t} 3}+\varepsilon_{\mathrm{t}}
\end{aligned}
$$

Panel $\mathrm{D}$ of Table 3 reports the test results. The coefficient on $\mathrm{IS}_{\mathrm{t}} * \mathrm{CFO}_{\mathrm{t} 3}$ is significantly positive $\left(b_{11}=0.160\right.$, t-statistic $\left.=2.81\right)$, suggesting that the stock price of firms that engage in more income smoothing impounds more information about their future cash flows. This finding is consistent with our primary results when earnings are used. Note that the coefficient on $\mathrm{IS}_{\mathrm{t}} * \mathrm{ACC}_{\mathrm{t} 3}$ is also significantly positive $\left(\mathrm{b}_{14}=0.264\right.$, t-statistic $=4.79)$, indicating that stock price also captures more information about future accruals when firms report smoother earnings.

\footnotetext{
${ }^{10}$ Another reason for the earnings decomposition is that smoothing reduces the variance of earnings, and thus may increase the ERC and FERC by construction.
} 


\section{Controlling for Potentially Omitted Correlated Variables}

We are concerned that the statistical significance relating to income smoothing may be due to omitted correlated variables. Other factors could make stock price impound more information about future earnings. Omitting these factors would overstate the statistical inference of IS. For example, larger firms may make more disclosures for fear of litigation risk (Kasznik and Lev 1995; Johnson, Kasznik and Nelson 2001). Anticipating future access to the capital markets, firms with higher growth prospects perhaps disclose more forward-looking information to reduce information asymmetry (Frankel, McNichols and Wilson 1995). If a firm's future earnings are volatile, they are more difficult to predict and thus the amount of future earnings information impounded in current stock price is low. In addition, a firm's stock price probably impounds more information about future earnings when there are more private information search activities by analysts and institutional investors.

To address these concerns, we control for firm size, growth, future earnings variability, analyst following, and institutional holdings. Firm size ("Size") is measured as the market value of common equity at the beginning of Year $t$ (Compustat Data199*Data25). Firm growth is proxied by the book-to-market ratio ("BM") at the beginning of Year t (Penman 1996), which is measured as the ratio of book value of common equity (Compustat Data60) over market value of equity. For future earnings variability ("EarnStd"), we use the standard deviation of EPS (Compustat Data58, adjusted for stock splits and stock dividends) for Year $t+1$ to $t+3$, deflated by the stock

price at the beginning of Year $t$. These data requirements reduce the number of observations from 17,019 to 17,011 . 
Analyst following ("Analysts") is measured as the average number of analysts' forecasts included in the monthly consensus, compiled by IBES during Year t. Among the 17,011 observations, 11,879 are covered by IBES with the mean and median analyst coverage being 7.746 and 4.909, respectively (untabulated). Following Frankel and Li (2004), we set the number of analyst following to zero if a firm-year is not covered by IBES.

Institutional holdings ("Institution") are obtained from CDA/Spectrum and measured as the average proportion of shares held by institutional investors at the end of each quarter of Year t. The variable is treated as missing if a firm-year is not covered by $\mathrm{CDA} /$ Spectrum. We delete 61 observations for which the institutional holding ratio is larger than 1 (data error). For the remaining 16,950 observations, 13,954 are covered by $\mathrm{CDA} /$ Spectrum with the mean and median institutional holding ratio being 0.367 and 0.356 , respectively (untabulated).

The new control variables are converted into fractional rankings within their industryyear before they enter the regression. ${ }^{11}$ We add new control variables to the primary model one at a time, referred to as " $\mathrm{Z}_{\mathrm{t}}$ " in Regression (7). The control is exercised through the interaction $Z_{t} * X_{t 3}$. The mean effect of $Z_{t}$ is included because omitting it would make the interpretation of $Z_{\mathrm{t}} * X_{\mathrm{t} 3}$ problematic if $Z_{\mathrm{t}}$ directly affects returns.

$$
\begin{aligned}
\mathrm{R}_{\mathrm{t}}= & \mathrm{b}_{0}+\mathrm{b}_{1} \mathrm{X}_{\mathrm{t}-1}+\mathrm{b}_{2} \mathrm{X}_{\mathrm{t}}+\mathrm{b}_{3} \mathrm{X}_{\mathrm{t} 3}+\mathrm{b}_{4} \mathrm{R}_{\mathrm{t} 3}+\mathrm{b}_{5} \mathrm{IS}_{\mathrm{t}}+\mathrm{b}_{6} \mathrm{IS}_{\mathrm{t}} * \mathrm{X}_{\mathrm{t}-1} \\
& +\mathrm{b}_{7} \mathrm{IS}_{\mathrm{t}} * \mathrm{X}_{\mathrm{t}}+\mathrm{b}_{8} \mathrm{IS}_{\mathrm{t}} * \mathrm{X}_{\mathrm{t} 3}+\mathrm{b}_{9} \mathrm{IS}_{\mathrm{t}} * \mathrm{R}_{\mathrm{t} 3}+\mathrm{b}_{10} \mathrm{Z}_{\mathrm{t}}+\mathrm{b}_{11} \mathrm{Z}_{\mathrm{t}} * X_{\mathrm{t} 3}+\varepsilon_{\mathrm{t}}
\end{aligned}
$$

Panel A of Table 4 reports the estimation results. Throughout the individual models, the coefficients on $\mathrm{IS}_{\mathrm{t}} * \mathrm{X}_{\mathrm{t} 3}$ remain significantly positive, supporting our previous

\footnotetext{
${ }^{11}$ In case of ties, the lowest corresponding ranks are assigned. For observations that are not covered by IBES, the analyst-coverage rankings are set to zero.
} 
conclusion that income smoothing improves earnings informativeness. In addition, future earnings variable " $\mathrm{X}_{\mathrm{t} 3}$ " interacts positively with firm size, growth, analyst following, and institutional holdings, and interacts negatively with future earnings variability. ${ }^{12}$ These results confirm that the information environment is richer for large high-growth firms and firms with high analyst coverage and institutional holdings, and that stock price contains less information about future earnings when these earnings are more difficult to predict.

Panel B reports the test results with all five new controls in place, using the observations that have institutional holdings data. The coefficient on $\mathrm{IS}_{\mathrm{t}} * \mathrm{X}_{\mathrm{t} 3}$ is weakly significantly positive in a two-tailed test $\left(b_{8}=0.118, t\right.$-statistic $\left.=1.83\right)$. The coefficients on the interactive terms for size, growth, and future earnings variability are similar to those in Panel A. In the presence of these controls, the level of analyst coverage is associated with lower FERC $\left(\mathrm{b}_{17}=-0.149, \mathrm{t} \text {-statistic }=-1.91\right)^{13}$, and institutional holdings are unrelated to FERC $\left(\mathrm{b}_{19}=-0.06\right.$, t-statistic $\left.=-0.66\right)$.

Finally, in Panel C, we create two dummy variables so that we can use the information about analyst following and institutional holdings, when the information is available, to estimate the coefficients relating to these two controls, and we can use the full sample to estimate other coefficients. "Dumcover, takes the value of 1 for the firmyears covered by IBES and 0 otherwise. "Dumhold" takes the value of 1 for those covered by $\mathrm{CDA} / \mathrm{Spectrum}$ and 0 otherwise. The results for the control variables are similar to those in Panel B. The reported coefficient on $\mathrm{IS}_{\mathrm{t}} * \mathrm{X}_{\mathrm{t} 3}$ is increased to 0.129,

\footnotetext{
${ }^{12}$ Alternatively, we run regressions in which each of the new control variables interacts with all existing independent variables and find similar results. To save space, we report our results for Regression (7) only.

${ }^{13}$ When only the analyst control is included for this sample of 13,954 observations, $Z_{t} * X_{t 3}$ has a coefficient of 0.369 with a t-statistic of 7.14, both of which are very similar to the results in Panel A for the full sample of 17,011 observations. This confirms that it is the additional controls, and not the change in sample, that reduces the effect of analyst coverage in the regression model in Panel B.
} 
significantly positive (t-statistic 2.26), confirming that income smoothing improves earnings informativeness.

\section{Profit vs. Loss Firms}

Prior research has demonstrated that profits are more value relevant than losses because (i) losses are more transitory (Basu 1997) and (ii) the values of loss firms are bounded below by the liquidation option (Hayn 1995). Among the 17,019 observations used for the main test, 4,391 observations (25.8\%) have current losses. In Regression (8), we add a dummy variable for current year losses and its interaction with $\mathrm{X}_{\mathrm{t}}$ and $\mathrm{X}_{\mathrm{t} 3}$.

$$
\begin{aligned}
\mathrm{R}_{\mathrm{t}}= & \mathrm{b}_{0}+\mathrm{b}_{1} \mathrm{X}_{\mathrm{t}-1}+\mathrm{b}_{2} \mathrm{X}_{\mathrm{t}}+\mathrm{b}_{3} \mathrm{X}_{\mathrm{t} 3}+\mathrm{b}_{4} \mathrm{R}_{\mathrm{t} 3} \\
& +\mathrm{b}_{5} \mathrm{IS}_{\mathrm{t}}+\mathrm{b}_{6} \mathrm{IS}_{\mathrm{t}} * \mathrm{X}_{\mathrm{t}-1}+\mathrm{b}_{7} \mathrm{IS}_{\mathrm{t}} * \mathrm{X}_{\mathrm{t}}+\mathrm{b}_{8} \mathrm{IS}_{\mathrm{t}} * \mathrm{X}_{\mathrm{t} 3}+\mathrm{b}_{9} \mathrm{IS}_{\mathrm{t}} * \mathrm{R}_{\mathrm{t} 3} \\
& +\mathrm{b}_{10} \operatorname{Loss}_{\mathrm{t}}+\mathrm{b}_{11} \operatorname{LosS}_{\mathrm{t}} * \mathrm{X}_{\mathrm{t}}+\mathrm{b}_{12} \operatorname{Loss}_{\mathrm{t}} * \mathrm{X}_{\mathrm{t} 3}+\varepsilon \varepsilon_{\mathrm{t}}
\end{aligned}
$$

Table 5 shows that, with this control, income-smoothing does not change the ERC but enhances the FERC (coefficient 0.172 and t-statistic 2.84), indicating that for these firms the stock price of higher income-smoothing firms compounds more information about future earnings than that of lower income-smoothing firms. For loss firms, both the ERC and FERC attenuate. The significantly negative coefficient on $\operatorname{Loss}_{t} * \mathrm{X}_{\mathrm{t}}$ indicates that the ERC for loss firms is lower than that for profit firms, consistent with prior research. The significantly negative coefficient on $\operatorname{Loss}_{\mathrm{t}} * \mathrm{X}_{\mathrm{t} 3}$ suggests that the stock price of loss firms reflects less information about their future earnings than that of profit firms.

\section{Fama-MacBeth Regressions}

In running cross-sectional regressions, the potential positive cross-sectional correlations of the residuals are a valid concern. If they exist, our inferences would have been overstated. To address this concern, we extend the sample period to pre-1988 data 
(before the advent of the cash flow statements) to obtain a large number of cross-sections for the Fama-MacBeth analysis. For pre-1988, we use the "balance sheet" approach to estimate total accruals. ${ }^{14}$ The longer time series also allows us to increase the number of observations for calculating the income-smoothing measure from 5 to 7 .

The results are reported in Table 6. The left columns of the table report the results of the primary model (4), and the right columns report the results of the extended model (6). The table reports the means, medians, and t-statistics of the three key coefficients in the 21 annual regressions from 1980 to 2000 . The mean coefficient on $\mathrm{IS}_{\mathrm{t}} * \mathrm{X}_{\mathrm{t}}$ is 0.565 , significantly positive in a two-tailed test (Fama-MacBeth t-statistic 4.65). The mean coefficient on $\mathrm{IS}_{\mathrm{t}} * \mathrm{X}_{\mathrm{t} 3}$ is 0.097 , weakly significantly positive in a two-tailed test (FamaMacBeth statistic 1.70). The right columns of the table report the earnings-decomposition regressions. The mean coefficients on $\mathrm{IS}_{\mathrm{t}} * \mathrm{CFO}_{\mathrm{t}}$ and on $\mathrm{IS}_{\mathrm{t}} * \mathrm{CFO}_{\mathrm{t} 3}$ are 0.388 and 0.162 , respectively, both significantly positive in a two-tailed test (Fama-MacBeth t-statistics 2.62 and 3.19 , respectively). Overall, the results confirm our primary test results.

In summary, the robustness-test results are consistent and support the conclusion that income smoothing improves earnings informativeness about future earnings and cash flows.

\section{CONCLUSION}

We use a new approach to investigate whether income smoothing garbles accounting earnings information or improves the informativeness of firms' current and past earnings about their future earnings and cash flows. We measure income smoothing as the

\footnotetext{
${ }^{14}$ The operating cash flows are measured as net income before extraordinary items minus the increase in noncash current assets, plus the increase in current liabilities (excluding the short-term portion of long-term debts) and plus depreciation expense (Collins and Hribar 2002).
} 
negative correlation of a firm's change in discretionary accruals with its change in premanaged income. A more negative correlation indicates more income smoothing.

Using the method of Collins, Kothari, Shanken and Sloan (1994), we find that a higher-smoothing firm's future earnings are impounded in its current stock price to a larger extent than that of a lower-smoothing firm. Such results are robust after we decompose earnings into operating cash flows and accruals; separate loss firms from profit firms; and control for firm size, growth, future earnings variability, private information search activities, and potential cross-sectional correlations. Thus, we document empirically that an important effect of managers' use of financial reporting discretion is to reveal more information about firms' future earnings and cash flows. Our work contributes to the literature by shedding new light on this information-vs-garbling debate.

Our results are subject to two caveats. First, the interpretation of our results critically relies upon the assumption of market efficiency. In the presence of mispricing, our results are subject to reinterpretation. Second, despite all our attempts to ensure that measurement error in the income-smoothing measure is not driving the results, we cannot rule out measurement error as an alternative explanation for the results.

Our paper presents the first empirical evidence that stock prices impound more information about future earnings when firms smooth their reported income. Perhaps more important than its results, the paper presents a new approach to studying the effects of earnings management. The informativeness methodology used here to study income smoothing can be applied to other types of earnings management and thus represents a promising area for future research. 


\section{REFERENCES}

Ayra, A., J. Glover and S. Sunder. 1998. Earnings management and the revelation principle. Review of Accounting Studies 3: 7-34.

Bartov, E. and P. Mohanram. 2004. Private information, earnings manipulations, and executive stock-option exercises. The Accounting Review 79 (4) (October): 889-900.

Basu, S. 1997. The conservatism principle and the asymmetric timeliness of earnings. Journal of Accounting and Economics 24 (1) (December): 3-37.

Beidleman, Carl. 1973. Income smoothing: The role of management. The Accounting Review 48 (4) (October): 653-667.

Christie, A. 1987. On cross-sectional analysis in accounting research. Journal of Accounting and Economics 9 (3): 231-258.

Collins, D. W. and P. Hribar. 2002. Errors in estimating accruals: Implications for empirical research. Journal of Accounting Research 40 (1): 105 -135.

Collins, D, S. P. Kothari, J. Shanken, and R. Sloan. 1994. Lack of timeliness and noise as explanations for the low contemporaneous return-earnings association. Journal of Accounting and Economics 18: 289-324.

Das, S. and P. K. Shroff. 2002. Fourth quarter reversals in earnings changes and earnings management. Working paper. University of Illinois at Chicago.

Dechow, P., A. Hutton, and R. Sloan. 1995. Detecting earnings management. The Accounting Review 70 (2): 193-225.

Demski, J. S. 1998. Performance measure manipulation. Contemporary Accounting Research 15 (3): 261-285.

Demski, J. S. and J. Christensen. 2002. Accounting theory: An information content perspective. McGraw-Hill/Irwin. $1^{\text {st }}$ edition.

Demski, J. S. and H. Frimor. 1999. Performance measure garbling under renegotiation in multi-period agencies. Journal of Accounting Research 37: 187-214.

Fama, Eugene and Kenneth French. 1992. The cross-section of expected stock returns. Journal of Finance 47: 427-465.

Fama, Eugene and Kenneth French. 1993. Common risk factors in the returns on stock and bonds. Journal of Financial Economics 33: 3-56.

Fama, E. and J. MacBeth. 1973. Risk, return, and equilibrium: Empirical tests. Journal of Political Economy: 81 (3) (May): 607-636.

Frankel, R. and X. Li. 2004. Characteristics of a firm's information environment and the information asymmetry between insiders and outsiders. Journal of Accounting and Economics 37: 229-259.

Frankel, R., M. McNichols and G. Wilson. 1995. Discretionary disclosure and external financing. The Accounting Review 70 (1): 135-150. 
Fudenberg, D. and J. Tirole. 1995. A theory of income and dividend smoothing based on incumbency rents. Journal of Political Economy 103 (1) (February): 75-93.

Gordon, M. J. 1964. Postulates, principles and research in accounting. The Accounting Review 39 (2) (April): 251-263.

Hayn, C. 1995. The information content of losses. Journal of Accounting and Economics 20: $125-153$.

Healy, P. 1985. The effect of bonus schemes on accounting decisions. Journal of Accounting and Economics 7 (1-3): 85-107,

Healy, P. and J. Wahlen. 2000. A review of the earnings management literature and its implications for standard setting. Accounting Horizons: 365-383

Hunt, A., S. Moyer, and T. Shevlin. 2000. Earnings volatility, earnings management, and equity value. Working paper. University of Washington.

Jacob, J. and B. Jorgensen. 2003. Earnings management and accounting income aggregation. Working paper. Columbia University.

Jones, J. 1991. Earnings management during import relief investigations. Journal of Accounting Research 29 (2) (Autumn): 193-228.

Johnson, M. F., R. Kasznik, and K. K. Nelson. 2001. The impact of securities litigation reform on the disclosure of forward-looking information by high technology firms. Journal of Accounting Research 39 (2) (September): 297-327.

Kasznik, R., and B. Lev. 1995. To warn or not to warn: management disclosures in the face of an earnings surprise. The Accounting Review 70 (1) (January): 113-134.

Kirschenheiter, M. and N. Melumad. 2002. Earnings quality and smoothing. Journal of Accounting Research 40 (3): 761-796.

Kothari, S. P., A. Leone, and C. Wasley. 2005. Performance matched discretionary accruals. Journal of Accounting and Economics 39 (1) (February): 161-197.

Lambert, R.. 1984. Income smoothing as rational equilibrium behavior. The Accounting Review 41 (4) (October): 604-618.

Leuz, C., D. Nanda, and P. Wysocki. 2003. Investor protection and earnings management. Journal of Financial Economics 69 (3) (September): 505-527.

Levitt, A. 1998. The numbers game. Speech delivered at NYU Center for Law and Business. New York, N.Y. September 28.

Lundholm, R. and L. Myers. 2002. Bringing the future forward: The effect of disclosure on the returns-earnings relation. Journal of Accounting Research 40 (3): 809-839.

Marquardt, C. and C. Wiedman. 2005. Earnings management through transaction structuring: Contingent convertible debt and diluted earnings per share. Journal of Accounting Research 43 (2) (May): 205-243.

Myers, L. and D. Skinner. 2002. Earnings momentum and earnings Management. Working paper. University of Michigan. 
Penman, S. 1996. The articulation of price-earnings ratio and market-to-book ratios and the evaluation of growth. Journal of Accounting Research 34 (2) (Autumn): 235-259.

Ronen, J. and S.Sadan, 1981, Smoothing income numbers: Objectives, means, and implications. Addison-Wesley Publishing Company.

Sankar, M. and K. R. Subramanyam. 2001. Reporting discretion and private information communication through earnings. Journal of Accounting Research 39 (2): 365-386.

Schipper, K. 1989. Earnings management. Accounting Horizons 3: 91-106.

Spence, M. 1973. Job market signaling. The Quarterly Journal of Economics 87 (3): 355374.

Subramanyam, K. R. 1996. The pricing of discretionary accruals. Journal of Accounting and Economics 22: 249-281.

Teoh, S. H., I. Welch and T. J. Wong. 1998. Earnings management and the long-run market performance of initial public offerings. Journal of Finance 53 (6) (December): 1935-1974.

Trueman, B. and S. Titman. 1988. An explanation for accounting income smoothing. Journal of Accounting Research 26: 127-139. 
Figure 1

The Relation between the FERC and Earnings Informativenss

In the Presence of Income Smoothing

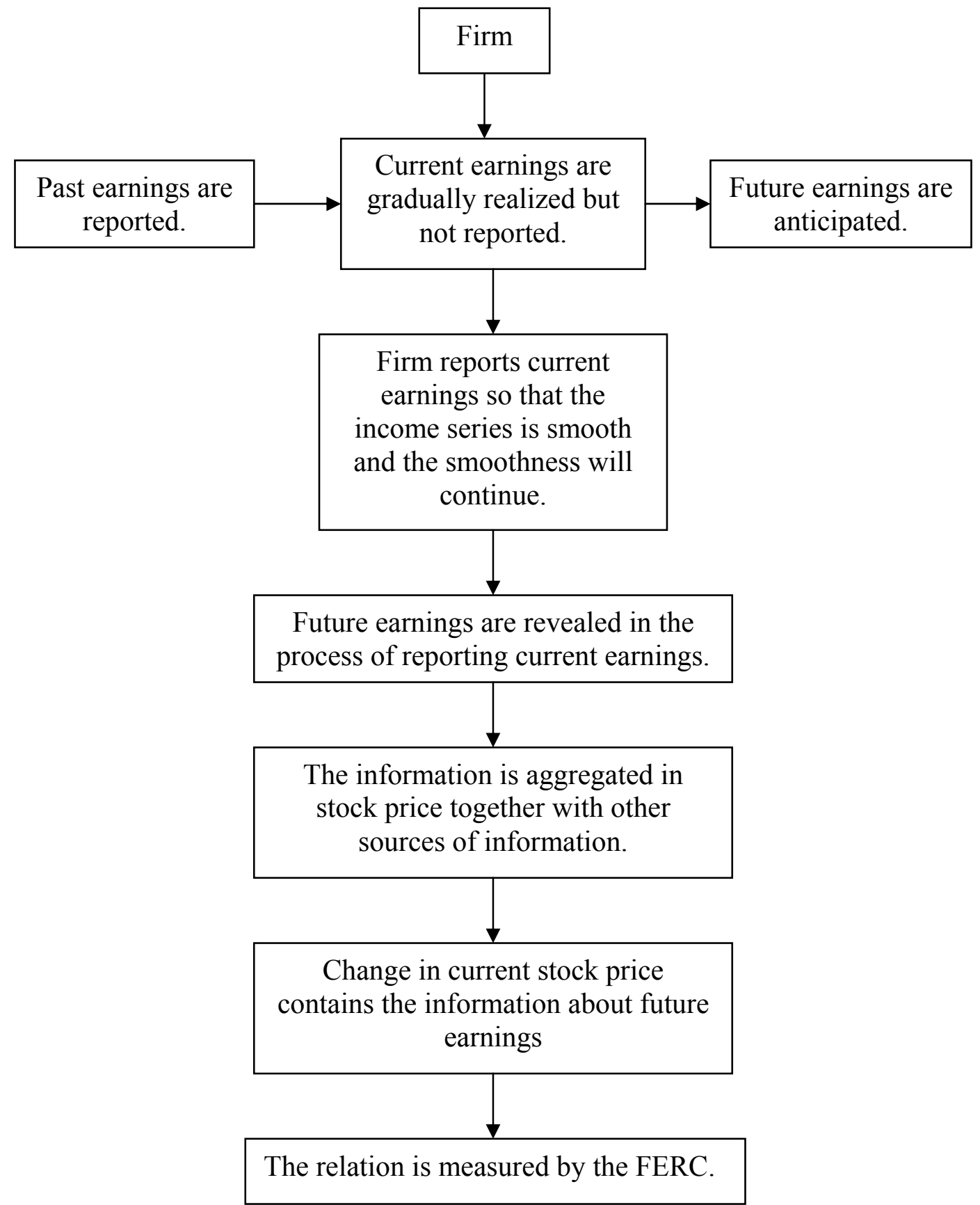




\section{Table 1}

\section{Cross-Sectional Estimation of Discretionary Accruals}

The Jones Model - modified by Kothari, Leone and Wasley (2004):

Accruals $_{\mathrm{t}}=\mathrm{a}\left(1 /\right.$ Assets $\left._{\mathrm{t}-1}\right)+\mathrm{b} \Delta$ Sales $_{\mathrm{t}}+\mathrm{c} \mathrm{PPE}_{\mathrm{t}}+\mathrm{d} \mathrm{ROA}_{\mathrm{t}}+\mu_{\mathrm{t}}$

\begin{tabular}{cccccc}
\hline Statistics & $\mathrm{a}$ & $\mathrm{B}$ & $\mathrm{c}$ & $\mathrm{D}$ & $\mathrm{R}^{2}$ \\
\hline mean & 0.112 & 0.013 & -0.074 & 0.457 & 0.642 \\
Std. Dev. & 2.528 & 0.191 & 0.129 & 0.326 & 0.229 \\
Median & 0.068 & 0.016 & -0.077 & 0.440 & 0.668 \\
Minimum & -60.167 & -3.072 & -1.289 & -0.810 & 0.031 \\
Maxmium & 6.413 & 1.003 & 1.819 & 1.743 & 1.000 \\
\hline
\end{tabular}

Notes:

1. The table presents the summary statistics of the estimated coefficients and $R^{2}$ of 650 industry-year regressions from 1988-2000, where industries are classified by the first two digits of the SIC code.

2. Variable Definitions:

(i) "Accruals s" are the total accruals in Fiscal Year $t$ obtained by subtracting operating cash flows from net income before extraordinary items and discontinued operations (Compustat Data18), deflated by the beginning-ofyear total assets (Compustat Data6).

(ii) "Assets t-1" are the total assets at the beginning of Fiscal Year t.

(iii) " $\Delta$ Sales $t$ " are the change in sales (Compustat Data12) from Fiscal Year t-1 to t.

(iv) "PPE " are the gross property, plant and equipment (Compustat Data7) at the end of Fiscal Year t.

(v) "ROA ${ }_{t}$ " is the ratio of net income over the beginning-of-year total assets for Fiscal Year t. 
Table 2

Sample Statistics

Panel A: Descriptive Statistics (17,019 firm-year observations during 1993-2000)

\begin{tabular}{|c|c|c|c|c|c|}
\hline Variable & Mean & Std. Dev. & Median & Minimum & Maximum \\
\hline $\mathrm{R}_{\mathrm{t}}$ & 0.153 & 0.688 & 0.047 & -0.949 & 10.000 \\
\hline$X_{t-1}$ & -0.002 & 0.185 & 0.043 & -3.480 & 0.370 \\
\hline$X_{t}$ & 0.015 & 0.145 & 0.047 & -1.985 & 0.508 \\
\hline$X_{t 3}$ & 0.074 & 0.362 & 0.125 & -3.154 & 2.238 \\
\hline $\mathrm{R}_{\mathrm{t} 3}$ & 0.335 & 1.162 & 0.071 & -0.998 & 9.992 \\
\hline $\mathrm{ACC}_{\mathrm{t}}$ & -0.070 & 0.165 & -0.038 & -2.177 & 0.609 \\
\hline $\mathrm{CFO}_{\mathrm{t}}$ & 0.086 & 0.151 & 0.078 & -1.043 & 1.246 \\
\hline $\operatorname{Corr}\left(\Delta \mathrm{DAP}_{\mathrm{t}}, \Delta \mathrm{PDI}_{\mathrm{t}}\right)$ & -0.709 & 0.418 & -0.899 & -1.000 & 1.000 \\
\hline DAP $_{t}$ & -0.047 & 0.525 & -0.023 & -41.540 & 4.349 \\
\hline
\end{tabular}

Panel B: Pairwise Pearson (Spearman) Correlations above (below) the Diagonal (17,019 observations)

\begin{tabular}{|c|c|c|c|c|c|c|}
\hline & $\mathrm{R}_{\mathrm{t}}$ & $\mathrm{X}_{\mathrm{t}-1}$ & $\mathrm{X}_{\mathrm{t}}$ & $X_{t 3}$ & $\mathrm{R}_{\mathrm{t} 3}$ & $\operatorname{Corr}\left(\Delta \mathrm{DAP}_{t}, \Delta \mathrm{PDI}_{\mathrm{t}}\right)$ \\
\hline $\mathrm{R}_{\mathrm{t}}$ & & -0.020 & 0.188 & 0.080 & -0.115 & $0.006^{\#}$ \\
\hline$X_{t-1}$ & 0.090 & & 0.466 & 0.315 & 0.040 & -0.201 \\
\hline$X_{t}$ & 0.401 & 0.547 & & 0.450 & 0.040 & -0.170 \\
\hline$X_{t 3}$ & 0.292 & 0.395 & 0.532 & & 0.363 & -0.138 \\
\hline $\mathrm{R}_{\mathrm{t} 3}$ & -0.069 & 0.146 & 0.141 & 0.539 & & -0.022 \\
\hline $\operatorname{Corr}\left(\Delta \mathrm{DAP}_{\mathrm{t}}, \Delta \mathrm{PDI}_{\mathrm{t}}\right)$ & -0.058 & -0.243 & -0.216 & -0.188 & -0.091 & \\
\hline
\end{tabular}

Note: “\#” indicates statistically insignificance. The unmarked correlations are statistically significant at $5 \%$ or lower in a two-tailed test. 


\section{Table 2 \\ Sample Statistics \\ (Continued)}

Variable Definitions:

(i) " $\mathrm{R}_{t}$ " is the ex-dividend stock return during Fiscal Year $\mathrm{t}$.

(ii) " $\mathrm{X}_{\mathrm{t}-1}$ " is the earnings per share (Compustat Data58, adjusted for stock splits and stock dividends) for Fiscal Year $\mathrm{t}-1$, deflated by the stock price at the beginning of Fiscal Year $t$.

(iii) " $\mathrm{X}$ " is the earnings per share for Fiscal Year $\mathrm{t}$, deflated by the stock price at the beginning of Fiscal Year $t$.

(iv) " $\mathrm{X}_{\mathrm{t} 3}$ " is the sum of earnings per share for Fiscal Year $\mathrm{t}+1$ through $\mathrm{t}+3$, deflated by the stock price at the beginning of Fiscal Year $t$.

(v) " $\mathrm{R}_{\mathrm{t} 3}$ " is the annually compounded stock return for Fiscal Year $\mathrm{t}+1$ through $\mathrm{t}+3$.

(vi) "ACC $\mathrm{t}_{\mathrm{t}}$ " are the total accruals in Fiscal Year $\mathrm{t}$ obtained by subtracting operating cash flows from net income before extraordinary items and discontinued operations (Compustat Data18). To prepare for the returns regression, different from "Accruals" in Table 1, this variable is deflated by the market value at the beginning of Fiscal Year $t$.

(vii) "CFO $t$ " are the cash flows from operations reported in the cash flow statements (Compustat Data308) for Fiscal Year t, deflated by the market value at the beginning of the year.

(viii) "Corr ( $\left.\triangle \mathrm{DAP}_{\mathrm{t}}, \triangle \mathrm{PDI} \mathrm{t}_{\mathrm{t}}\right)$ " is the Pearson correlation between the change in discretionary accruals and the change in pre-managed income.

(ix) "DAP ${ }_{t}$ " is the discretionary accruals for Fiscal Year $t$, which are deflated by the beginning-of-year total assets. 
Table 3

Main Tests

Panel A: Earnings-Persistence Model:

$$
\begin{aligned}
& \text { EPS }_{\mathrm{t} 3}=\mathrm{a}_{0}+\mathrm{a}_{1} \text { EPS }_{\mathrm{t}}+\mathrm{a}_{2} \text { IS }_{\mathrm{t}}+\mathrm{a}_{3} \text { IS }_{\mathrm{t}} * \text { EPS }_{\mathrm{t}}+\varepsilon_{\mathrm{t}} \\
& \begin{array}{llll}
0.157 & 1.034 & 0.658 & 0.703
\end{array} \\
& \begin{array}{llll}
(2.74) & (32.06) & (6.56) \quad(11.24)
\end{array}
\end{aligned}
$$

Panel B: Benchmark CKSS Model

$$
\begin{array}{cccccc}
\mathrm{R}_{\mathrm{t}}=\mathrm{b}_{0}+\mathrm{b}_{1} \mathrm{X}_{\mathrm{t}-1}+\mathrm{b}_{2} \mathrm{X}_{\mathrm{t}}+\mathrm{b}_{3} \mathrm{X}_{\mathrm{t} 3}+\mathrm{b}_{4} \mathrm{R}_{\mathrm{t} 3}+\mathrm{u}_{\mathrm{t}} & \text { Adjusted } \mathrm{R}^{2} \\
0.155 & -0.535 & 1.074 & 0.146 & -0.086 & 0.068 \\
(28.93) & (-17.07) & (25.04) & (8.46) & (-18.15) &
\end{array}
$$

Panel C: Primary Model

$$
\begin{aligned}
& \mathrm{R}_{\mathrm{t}}=\mathrm{b}_{0}+\mathrm{b}_{1} \mathrm{X}_{\mathrm{t}-1}+\mathrm{b}_{2} \mathrm{X}_{\mathrm{t}}+\mathrm{b}_{3} \mathrm{X}_{\mathrm{t} 3}+\mathrm{b}_{4} \mathrm{R}_{\mathrm{t} 3} \\
& \text { Adjusted } \mathrm{R}^{2} \\
& \begin{array}{lllll}
0.186 & -0.296 & 0.856 & -0.002 & -0.084
\end{array} \\
& \text { (16.30) (-5.66) (11.21) (-0.07) (-8.88) } \\
& 0.072 \\
& +b_{5} \text { IS }_{t}+b_{6} I S_{t} * X_{t-1}+b_{7} I_{S_{t}} * X_{t}+b_{8} I S_{t} * X_{t 3}+b_{9} I_{t} * R_{t 3}+\varepsilon_{t} \\
& \begin{array}{lllll}
-0.069 & -0.686 & 0.681 & 0.308 & -0.007
\end{array} \\
& \begin{array}{llll}
(-3.61) & (-5.51) \quad(4.08) \quad(4.99) \quad(-0.43)
\end{array}
\end{aligned}
$$

Panel D: Extended Model - earnings decomposition

$$
\begin{aligned}
& \mathrm{R}_{\mathrm{t}}=\mathrm{b}_{0}+\mathrm{b}_{1} \mathrm{CFO}_{\mathrm{t}-1}+\mathrm{b}_{2} \mathrm{CFO}_{\mathrm{t}}+\mathrm{b}_{3} \mathrm{CFO}_{\mathrm{t} 3}+\mathrm{b}_{4} \mathrm{ACC}_{\mathrm{t}-1}+\mathrm{b}_{5} \mathrm{ACC}_{\mathrm{t}}+\mathrm{b}_{6} \mathrm{ACC}_{\mathrm{t} 3}+\mathrm{b}_{7} \mathrm{R}_{\mathrm{t} 3} \\
& \begin{array}{llllllll}
0.131 & -0.829 & 1.065 & 0.064 & -0.227 & 0.657 & -0.183 & -0.085
\end{array} \\
& \begin{array}{lllllll}
(9.61) & (-8.25) \quad(10.09) & (2.02) & (-3.93) & (8.77) & (-6.13) & (-9.10)
\end{array} \\
& +\mathrm{b}_{8} \mathrm{IS}_{\mathrm{t}}+\mathrm{b}_{9} \mathrm{IS}_{\mathrm{t}} * \mathrm{CFO}_{\mathrm{t}-1}+\mathrm{b}_{10} \mathrm{IS}_{\mathrm{t}} * \mathrm{CFO}_{\mathrm{t}}+\mathrm{b}_{11} \mathrm{IS}_{\mathrm{t}} * \mathrm{CFO}_{\mathrm{t} 3} \\
& \begin{array}{llll}
-0.064 & 0.023 & 0.589 & 0.160
\end{array} \\
& \begin{array}{llll}
(-2.76) & (0.13) & (2.96)
\end{array} \\
& +\mathrm{b}_{12} \mathrm{IS}_{\mathrm{t}} * \mathrm{ACC}_{\mathrm{t}-1}+\mathrm{b}_{13} \mathrm{IS}_{\mathrm{t}} * \mathrm{ACC}_{\mathrm{t}}+\mathrm{b}_{14} \mathrm{IS}_{\mathrm{t}} * \mathrm{ACC}_{\mathrm{t} 3}+\mathrm{b}_{15} \mathrm{IS}_{\mathrm{t}} * \mathrm{R}_{\mathrm{t} 3}+\varepsilon_{\mathrm{t}} \quad \text { Adjusted } \mathrm{R}^{2} \\
& -0.687 \\
& \text { (-5.02) } \\
& 0.924 \\
& \text { (5.61) } \\
& 0.264 \\
& \text { (4.79) } \\
& -0.002 \\
& \text { (-0.10) }
\end{aligned}
$$




\section{Table 3 \\ Main Tests \\ (Continued)}

Notes:

1. The number of observations is 17,019 .

2. Variable Definitions:

(i) " $\mathrm{R}_{\mathrm{t}}$ " is the ex-dividend stock return for Fiscal Year $\mathrm{t}$.

(ii) "EPS ${ }_{t}$ " is the earnings per share (Compustat Data58, adjusted for stock splits and stock dividends) for Fiscal Year $t$, undeflated.

(iii) "EPS $t_{t 3}$ " is the sum of earnings per share for Fiscal Year $\mathrm{t}+1$ through $\mathrm{t}+3$, undeflated.

(iv) " $\mathrm{X}_{\mathrm{t}-1}$ " is the earnings per share (Compustat Data58, adjusted for stock splits and stock dividends) for Fiscal Year t-1, deflated by the stock price at the beginning of Fiscal Year t.

(v) " $\mathrm{X}$ " is the earnings per share for Fiscal Year $\mathrm{t}$, deflated by the stock price at the beginning of Fiscal Year $t$.

(vi) " $\mathrm{X}_{\mathrm{t} 3}$ " is the sum of earnings per share for Fiscal Year $\mathrm{t}+1$ through $\mathrm{t}+3$, deflated by the stock price at the beginning of Fiscal Year $t$.

(vii) " $\mathrm{R}_{\mathrm{t} 3}$ " is the annually compounded stock return for Fiscal Year $\mathrm{t}+1$ through $\mathrm{t}+3$.

(viii) "IS $\mathrm{t}$ " is the reversed fractional ranking of the Pearson correlation between the current year and past four years' change in discretionary accruals and change in pre-managed income.

(ix) "CFO t-1" are the operating cash flows (Compustat Data308) for Fiscal Year $\mathrm{t}-1$, deflated by the market value at the beginning of Fiscal Year $\mathrm{t}$.

(x) "CFO " are the operating cash flows for Fiscal Year $t$, deflated by the market value at the beginning of Fiscal Year $t$.

(xi) "CFO t3" are the operating cash flows for Fiscal Year $\mathrm{t}+1$ through $\mathrm{t}+3$, deflated by the market value at the beginning of Fiscal Year $t$.

(xii) "ACC $t-1$ " are the total accruals for Fiscal Year t-1, obtained by subtracting operating cash flows (Compustat Data308) from net income before extraordinary items and discontinued operations (Compustat Data18), deflated by the market value at the beginning of Fiscal Year $t$.

(xiii) "ACC " are the total accruals for Fiscal Year $t$, deflated by the market value at the beginning of Fiscal Year $t$.

(xiv) "ACC $\mathrm{t}_{3}$ " are the total accruals for Fiscal Year $\mathrm{t}+1$ through $\mathrm{t}+3$, deflated by the market value at the beginning of Fiscal Year $t$. 
Table 4

Robustness Tests

\section{Controlling for Potentially Omitted Correlated Variables}

Panel A: Adding a single new control variable $\mathrm{Z}_{\mathrm{t}}$ (Variable definitions are provided at the end of the table)

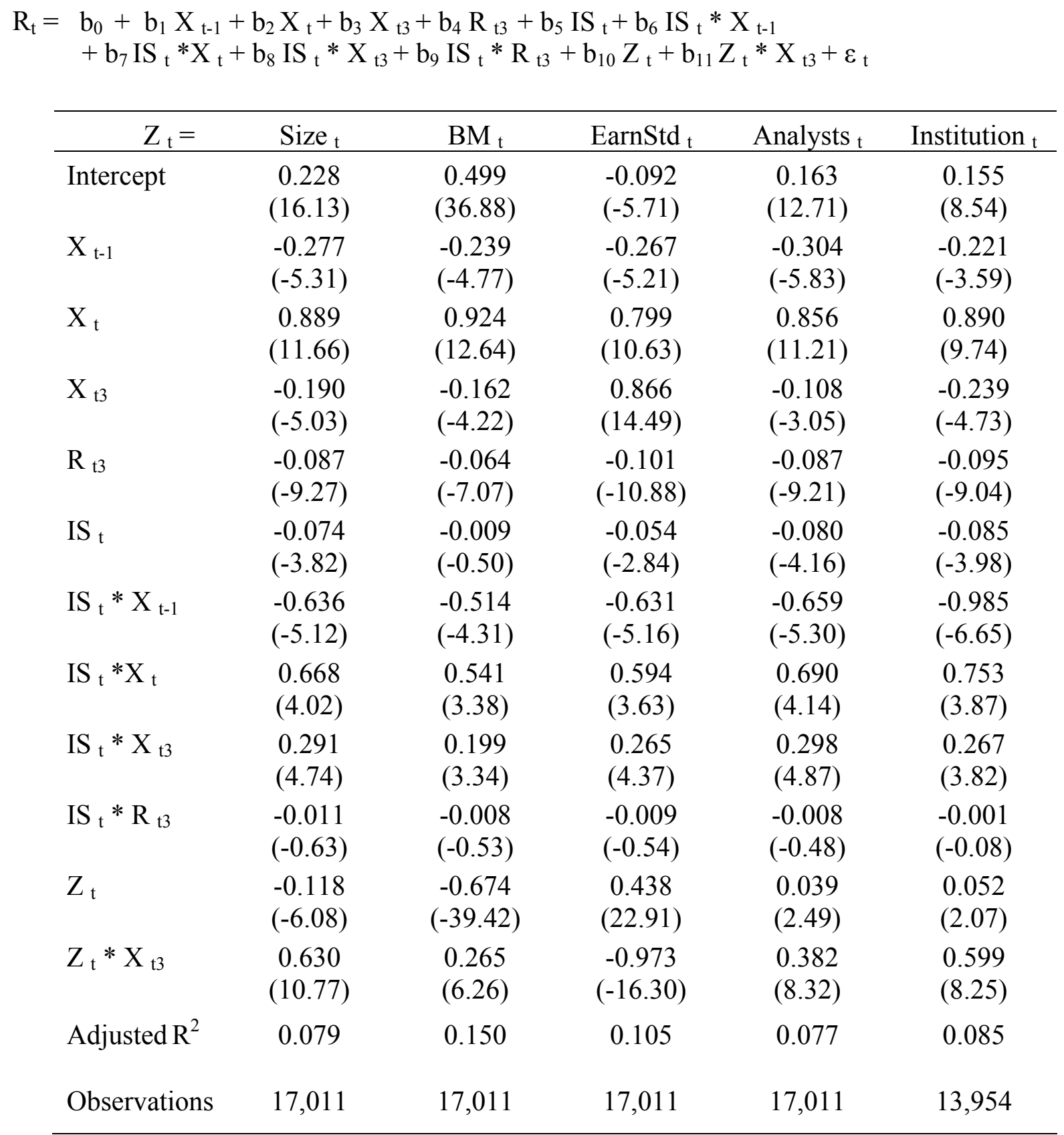




\section{Table 4 Robustness Tests \\ Controlling for Potentially Omitted Correlated Variables \\ (Continued)}

Panel B: Full Model (13,954 observations that have institutional holdings data)

$$
\begin{aligned}
& \mathrm{R}_{\mathrm{t}}=\mathrm{b}_{0}+\mathrm{b}_{1} \mathrm{X}_{\mathrm{t}-1}+\mathrm{b}_{2} \mathrm{X}_{\mathrm{t}}+\mathrm{b}_{3} \mathrm{X}_{\mathrm{t} 3}+\mathrm{b}_{4} \mathrm{R}_{\mathrm{t} 3} \\
& \begin{array}{lllll}
0.316 & -0.029 & 0.964 & 0.555 & -0.089
\end{array} \\
& \begin{array}{lllll}
(12.65) & (-0.53) & (11.66) & (7.02) & (-9.37)
\end{array} \\
& +b_{5} I_{\mathrm{t}}+\mathrm{b}_{6} \mathrm{IS}_{\mathrm{t}} * \mathrm{X}_{\mathrm{t}-1}+\mathrm{b}_{7} \mathrm{IS}_{\mathrm{t}} * \mathrm{X}_{\mathrm{t}}+\mathrm{b}_{8} \mathrm{IS}_{\mathrm{t}} * \mathrm{X}_{\mathrm{t} 3}+\mathrm{b}_{9} \mathrm{IS}_{\mathrm{t}} * \mathrm{R}_{\mathrm{t} 3} \\
& \begin{array}{lllll}
0.052 & -0.720 & 0.351 & 0.118 & -0.015
\end{array} \\
& \begin{array}{llll}
(2.67) \quad(-5.37) \quad(1.99) \quad(1.83) \quad(-0.90)
\end{array} \\
& +b_{10} \operatorname{Size}_{t}+b_{11} \operatorname{Size}_{t} * X_{t 3}+b_{12} B_{t}+b_{13} B_{t}^{*} X_{t 3}+b_{14} \text { EarnStd }_{t}+b_{15} \operatorname{EarnStd}_{t} * X_{t 3} \\
& \begin{array}{llllll}
-0.551 & 0.621 & -0.965 & 0.474 & 0.639 & -1.012
\end{array} \\
& \begin{array}{lllll}
(-15.53) & (5.82) & (-48.76) & (9.81) & (30.27)
\end{array}
\end{aligned}
$$
0.164
$-0.149$
0.229
$-0.060$
(5.87)
$(-1.91)$
(7.48)
$(-0.66)$

Panel C: Full Model (16,950 observations)

$$
\begin{aligned}
& \mathrm{R}_{\mathrm{t}}=\mathrm{b}_{0}+\mathrm{b}_{1} \mathrm{X}_{\mathrm{t}-1}+\mathrm{b}_{2} \mathrm{X}_{\mathrm{t}}+\mathrm{b}_{3} \mathrm{X}_{\mathrm{t} 3}+\mathrm{b}_{4} \mathrm{R}_{\mathrm{t} 3} \\
& \begin{array}{lllll}
0.323 & -0.135 & 0.920 & 0.560 & -0.082
\end{array} \\
& \begin{array}{lllll}
(13.31) & (-2.84) & (13.16) & (8.19) & (-9.50)
\end{array} \\
& +b_{5} I S_{t}+b_{6} I S_{t} * X_{t-1}+b_{7} I S_{t} * X_{t}+b_{8} I S_{t} * X_{t 3}+b_{9} I S_{t} * R_{t 3} \\
& \begin{array}{lllll}
0.051 & -0.335 & 0.353 & 0.129 & -0.018
\end{array} \\
& \begin{array}{llll}
(2.85) & (-2.95) \quad(2.32) & (2.26) \quad(-1.19)
\end{array} \\
& +b_{10} \text { Size }_{t}+b_{11} \text { Size }_{t} * X_{t 3}+b_{12} \text { BM }_{t}+b_{13} B_{t}^{*} X_{t 3}+b_{14} \text { EarnStd }_{t}+b_{15} \text { EarnStd }_{t} * X_{t 3} \\
& \begin{array}{llllll}
-0.491 & 0.532 & -0.894 & 0.376 & 0.619 & -0.978
\end{array} \\
& \begin{array}{lllll}
(-15.45) & (5.92) & (-49.76) & (8.95) & (32.00)
\end{array} \\
& +b_{16}\left(\text { Analysts }_{\mathrm{t}} * \text { Dumcover }_{\mathrm{t}}\right)+\mathrm{b}_{17}\left(\text { Analysts }_{\mathrm{t}} * \text { Dumcover }_{\mathrm{t}}\right) * \mathrm{X}_{\mathrm{t} 3} \\
& 0.191 \\
& \text { (5.14) } \\
& -0.148 \\
& (-2.15) \\
& +\mathrm{b}_{18}\left(\text { Insitution }_{\mathrm{t}}^{*} \text { Dumhold }_{\mathrm{t}}\right)+\mathrm{b}_{19}\left(\text { Insitution }_{\mathrm{t}} * \text { Dumhold }_{\mathrm{t}}\right) * \mathrm{X}_{\mathrm{t} 3} \\
& 0.165 \\
& \text { (5.81) } \\
& 0.018 \\
& (0.32) \\
& +\mathrm{b}_{20} \text { Dumcover }_{\mathrm{t}}+\mathrm{b}_{21} \text { Dumhold }_{\mathrm{t}}+\varepsilon_{\mathrm{t}} \\
& -0.002 \quad-0.040 \\
& (-0.07) \quad(-2.06)
\end{aligned}
$$




\section{Table 4 \\ Robustness Tests \\ Controlling for Potentially Omitted Correlated Variables \\ (Continued)}

Notes:

1. The first four columns of Panel A use 17,011 observations. The number of observations is less than that in Table 3 because of missing data for firm size, $\mathrm{B} / \mathrm{M}$ and earnings variability ( 8 observations).

2. The last column of Panel A and Panel B use 13,954 observations that have institutional holdings data.

3. Panel $\mathrm{C}$ uses 16,950 observations. The number of observations is 61 less than 17,011 because of data error in institutional holdings. The estimation uses the IBES and CDA/Spectrum information when it is available, and uses the full sample to estimate the coefficients unrelated to analyst following and institutional holdings.

4. Variable definitions: the additional variables are defined below. See Table 3 for the definitions of other variables.

(i) "Size " is the within industry-year fractional ranking (between 0 and 1) of a firm's market value (Compustat Data199*Data25) at the beginning of Fiscal Year $\mathrm{t}$.

(ii) " $\mathrm{BM}$ " is the within industry-year fractional ranking (between 0 and 1) of a firm's book-to-market ratio (Compustat Data60 / (Data199*Data25)) at the beginning of Fiscal Year t.

(iii) "EarnStd " is the within industry-year fractional ranking (between 0 and 1) of a firm's standard deviation of earnings per share (Compustat Data58, adjusted for stock splits and stock dividends) for Fiscal Year $t+1$ to $t+3$, deflated by the stock price at the beginning of Fiscal Year $t$.

(iv) "Analysts ${ }_{\mathrm{t}}$ " is the within industry-year fractional ranking (between 0 and 1 ) of a firm's average number of analyst forecasts included in the monthly consensus, compiled by IBES during the fiscal year. If a firm-year is not covered by IBES, the number of analyst following is set to 0 .

(v) "Institution ${ }_{\mathrm{t}}$ " is the within industry-year fractional ranking (between 0 and 1) of a firm's average proportion of shares held by institutional investors at the end of each quarter of Fiscal Year $t$, obtained from the CDA/Spectrum database. If a firm-year is not covered by CDA/Spectrum, this variable is treated as missing in Panel B and the last column of Panel A, and is set to 0 in Panel C.

(vi) "Dumcover ${ }_{\mathrm{t}}$ " is 1 if a firm-year is covered by IBES and 0 otherwise.

(vii) "Dumhold ${ }_{\mathrm{t}}$ " is 1 if a firm-year is covered by the CDA/Spectrum institutional holdings database and 0 otherwise. 
Table 5

Robustness Tests

Profit vs. Loss Firms

$$
\begin{aligned}
& \mathrm{R}_{\mathrm{t}}=\mathrm{b}_{0}+\mathrm{b}_{1} \mathrm{X}_{\mathrm{t}-1}+\mathrm{b}_{2} \mathrm{X}_{\mathrm{t}}+\mathrm{b}_{3} \mathrm{X}_{\mathrm{t} 3}+\mathrm{b}_{4} \mathrm{R}_{\mathrm{t} 3}+\mathrm{b}_{5} \mathrm{IS}_{\mathrm{t}}+\mathrm{b}_{6} \mathrm{IS}_{\mathrm{t}} * \mathrm{X}_{\mathrm{t}-1} \quad \text { Adjusted } \mathrm{R}^{2} \\
& \begin{array}{llllllll}
-0.000 & -0.260 & 3.608 & 0.116 & -0.079 & -0.053 & -0.415 & 0.123
\end{array}
\end{aligned}
$$

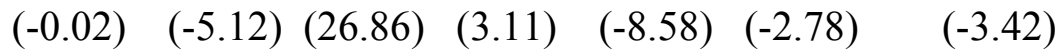

$$
\begin{aligned}
& +\mathrm{b}_{7} \mathrm{IS}_{\mathrm{t}} * \mathrm{X}_{\mathrm{t}}+\mathrm{b}_{8} \mathrm{IS}_{\mathrm{t}} * \mathrm{X}_{\mathrm{t} 3}+\mathrm{b}_{9} \mathrm{IS}_{\mathrm{t}} * \mathrm{R}_{\mathrm{t}} \\
& 0.082 \quad 0.172 \quad-0.010 \\
& \begin{array}{lll}
(0.50) \quad(2.84) \quad(-0.63)
\end{array} \\
& +b_{10} \operatorname{Loss}_{t}+b_{11} \operatorname{Loss}_{t} * X_{t}+b_{12} \operatorname{Loss}_{t} * X_{t 3}+\varepsilon_{t} \\
& -0.004 \quad-3.259 \quad-0.334 \\
& (-0.25) \quad(-25.67) \quad(-10.28)
\end{aligned}
$$

Notes: See Table 3 for the definitions for other variables.

1. "Loss $\mathrm{t}$ " is 1 if a firm reports negative earnings for Fiscal Year $t$ and 0 otherwise.

2. The number of observations is 17,019 . 


\section{Table 6 \\ Robustness Tests \\ Fama-MacBeth Regressions}

Primary Model

$$
\begin{aligned}
\mathrm{R}_{\mathrm{t}}=\mathrm{b}_{0} & +\mathrm{b}_{1} \mathrm{X}_{\mathrm{t}-1}+\mathrm{b}_{2} \mathrm{X}_{\mathrm{t}}+\mathrm{b}_{3} \mathrm{X}_{\mathrm{t} 3}+\mathrm{b}_{4} \mathrm{R}_{\mathrm{t} 3}+\mathrm{b}_{5} \mathrm{IS}_{\mathrm{t}}+\mathrm{b}_{6} \mathrm{IS}_{\mathrm{t}} * \mathrm{X}_{\mathrm{t}-1} \\
& +\mathrm{b}_{7} \text { IS }_{\mathrm{t}} * \mathrm{X}_{\mathrm{t}}+\mathrm{b}_{8} \text { IS }_{\mathrm{t}} * \mathrm{X}_{\mathrm{t} 3}+\mathrm{b}_{9} \text { IS }_{\mathrm{t}} * \mathrm{R}_{\mathrm{t} 3}+\varepsilon_{\mathrm{t}}
\end{aligned}
$$

Extended Model

$$
\begin{aligned}
\mathrm{R}_{\mathrm{t}}=\mathrm{b}_{0} & +\mathrm{b}_{1} \mathrm{CFO}_{\mathrm{t}-1}+\mathrm{b}_{2} \mathrm{CFO}_{\mathrm{t}}+\mathrm{b}_{3} \mathrm{CFO}_{\mathrm{t} 3}+\mathrm{b}_{4} \mathrm{ACC}_{\mathrm{t}-1}+\mathrm{b}_{5} \mathrm{ACC}_{\mathrm{t}}+\mathrm{b}_{6} \mathrm{ACC}_{\mathrm{t} 3}+\mathrm{b}_{7} \mathrm{R}_{\mathrm{t} 3} \\
& +\mathrm{b}_{8} \mathrm{IS}_{\mathrm{t}}+\mathrm{b}_{9} \mathrm{IS}_{\mathrm{t}} * \mathrm{CFO}_{\mathrm{t}-1}+\mathrm{b}_{10} \mathrm{IS}_{\mathrm{t}} * \mathrm{CFO}_{\mathrm{t}}+\mathrm{b}_{11} \mathrm{IS}_{\mathrm{t}} * \mathrm{CFO}_{\mathrm{t} 3} \\
& +\mathrm{b}_{12} \mathrm{IS}_{\mathrm{t}} * \mathrm{ACC}_{\mathrm{t}-1}+\mathrm{b}_{13} \mathrm{IS}_{\mathrm{t}} * \mathrm{ACC}_{\mathrm{t}}+\mathrm{b}_{14} \mathrm{IS}_{\mathrm{t}} * \mathrm{ACC}_{\mathrm{t} 3}+\mathrm{b}_{15} \mathrm{IS}_{\mathrm{t}} * \mathrm{R}_{\mathrm{t} 3}+\varepsilon_{\mathrm{t}}
\end{aligned}
$$

\begin{tabular}{l|ccc|ccc}
\hline \multirow{2}{*}{$\begin{array}{l}\text { Time-Series } \\
\text { Statistics }\end{array}$} & \multicolumn{3}{|c|}{ Primary Model } & \multicolumn{3}{c}{ Extended Model } \\
& $\mathrm{X}_{\mathrm{t}}$ & $\mathrm{IS}_{\mathrm{t}} * \mathrm{X}_{\mathrm{t}}$ & $\mathrm{IS}_{\mathrm{t}} * \mathrm{X}_{\mathrm{t} 3}$ & $\mathrm{CFO}_{\mathrm{t}}$ & $\mathrm{IS}_{\mathrm{t}} * \mathrm{CFO}_{\mathrm{t}}$ & $\mathrm{IS}_{\mathrm{t}} * \mathrm{CFO}_{\mathrm{t} 3}$ \\
\hline Mean & 0.887 & 0.565 & 0.097 & 1.062 & 0.388 & 0.162 \\
Median & 0.770 & 0.576 & 0.106 & 1.013 & 0.273 & 0.126 \\
$\begin{array}{l}\text { Fama-MacBeth } \\
\mathrm{t} \text { statistic }\end{array}$ & 11.76 & 4.65 & 1.70 & 10.26 & 2.62 & 3.19 \\
\hline
\end{tabular}

Notes:

1. See Table 3 for variable definitions.

2. The models are each run on 21 industry-year cross sections during 1980-2000. The Fama-MacBeth approach treats the coefficients from the annual regressions as i.i.d.

3. For firm-years post-1988, operating cash flows are obtained from Compustat Data308. For firm-years pre-1988, operating cash flows are calculated using the balance-sheet approach (Collins and Hribar, 2002).

4. Different from other tables, IS uses a firm's current and prior seven years' change in discretionary accruals and change in pre-managed income. 